Reviu Akuntansi dan Bisnis Indonesia, Vol. 4 No. 1, Hlm: 68-78, Juli 2020

Website: http://journal.umy.ac.id/index.php/rab

\title{
Pengaruh Kemanfaatan E-Filing, Pemahaman Wajib Pajak, Kualitas Pelayanan, dan Sanksi Perpajakan Terhadap Kepatuhan Wajib Pajak di Kabupaten Kulon Progo dan Sleman
}

\author{
Muhamad Aditya Firdaus ${ }^{1 *}$ \& Suryo Pratolo ${ }^{1}$ \\ 'Program Studi Akuntansi Univeritas Muhammadiyah Yogyakarta.
}

IN F O A R T I K E L

\section{Kata Kunci:}

Kemanfaatan E-Filing, Pemahaman Wajib Pajak, Kualitas Pelayanan, Sanksi Perpajakan, Kepatuhan Wajib Pajak

Jenis Artikel:

Penelitian Empiris

Korespondensi: Aditya120496@gmail.com

\section{A B S T R A K}

\section{Latar Belakang:}

Indonesia masih tertinggal dibandingkan dengan negara-negara tetangga seperti Malaysia yang sudah mencapai 13\%, bahkan untuk negara Vietnam dan Singapura sudah mencapai $16 \%$. Rendahnya tingkat kepatuhan wajib pajak di Indonesia mendorong pemerintah membuat strategi yang mampu mendorong wajib pajak untuk patuh membayar pajak. Maka, Kualitas pelayanan dapat ditingkatkan melalui peningkatan kemampuan dalam bidang perpajakan, memperluas tempat pelayanan terpadu, dan menggunakan sistem teknologi dan informasi.

\section{Tujuan:}

Tujuan penelitian ini adalah untuk mendapatkan bukti empiris pengaruh kemanfaatan E-Filing, pemahaman wajib pajak, kualitas pelayanan dan sanksi perpajakan terhadap kepatuhan wajib pajak.

\section{Metode Penelitian:}

Penelitian ini bersifat ex-post facto. Sampel penelitian ini adalah wajib pajak badan yang melaporkan SPT melalui E-Filing di kabupaten Kulonprogo dan Sleman. Teknik penggumpulan data menggunakan angket. Teknik analisis data menggunakan analisis regresi linier berganda. Hasil Penelitian:

Hasil penelitian menunjukkan bahwa, Kemanfaatan e-Filing berpengaruh signifikan terhadap kepatuhan wajib pajak, Pemahaman wajib pajak berpengaruh signifikan terhadap kepatuhan wajib pajak,Kualitas pelayanan pajak berpengaruh signifikan terhadap kepatuhan wajib pajak dan Sanksi pajak berpengaruh signifikan terhadap kepatuhan wajib pajak. Keterbatasan Penelitian:

Penelitian ini terbatas untuk wilayah Kabupaten Kulon Progo dan Sleman, maka masih perlu dilakukan penelitian lebih lanjut untuk mengetahui Kemanfaatan E-Filing, Pemahaman Wajib Pajak, Kualitas Pelayanan daerah lain.

Keaslian/Novetly Penelitian:

Penelitian terkait pajak masih terus berkembang, khususnya bidang sistem informasi pajak. Dan penelitian ini memberikan diskusi baru untuk bidang perpajakan. 


\section{PENDAHULUAN}

Indonesia menganut sistem perpajakan self assessment system, yaitu sistem pemungutan pajak yang memberikan wewenang dalam menghitung, membayar dan melaporkan sendiri pajak terutangnya (Dessy dkk, 2017). Namun, kondisi ini tidak mendorong wajib pajak untuk membayar pajak tepat waktu, masih banyak wajib pajak yang tidak patuh dalam membayar pajak, dalam arti membayar pajak di luar waktu yang ditentukan pemerintah. Menurut Direktur Penyuluhan, Pelayanan dan Hubungan Masyarakat Direktorat Jenderal Pajak, Hestu Yoga Saksama menyebutkan bahwa tingkat kepatuhan masyarakat Indonesia dalam membayar pajak masih rendah. Hal ini dapat dilihat dari tax ratio yang masih mencapai 10.3\% pada tahun 2017.

Indonesia masih tertinggal dibandingkan dengan negara-negara tetangga seperti Malaysia yang sudah mencapai 13\%, bahkan untuk negara Vietnam dan Singapura sudah mencapai 16\%. Selain itu menurut Direktur Eksekutif Center for Indonesia Taxation Analysis (CITA) Yustinus Prastowo, juga menyebutkan bahwa tingkat kepatuhan masyarakat Indonesia terhadap pajak masih rendah. Hal ini terlihat dari tax coverage ratio (nisbah realisasi terhadap potensi) yang baru mencapai $72 \%$ (Kusuma, 2018 diakses https://finance.detik.com/berita-ekonomi-bisnis/d-4214299/tingkatkepatuhan-pajak-masyarakat-ri-masih-rendah).

Jumlah wajib pajak di D.I Yogyakarta pada tahun 2017 mencapai 507.421 yang terbagi atas wajib pajak badan 36.284, obyek pajak non karyawan 73.998 dan obyek pajak karyawan 397.139. Jumlah SPT yang terdaftar sebanyak 240.575 dengan perincian badan sebanyak 19.053, obyek pajak non karyawan 25.411 dan obyek pajak karyawan sekitar 196.111. Berdasarkan data tersebut, terlihat bahwa tingkat kepatuhan obyek pajak badan memang yang paling rendah, yaitu hanya mencapai 41\% dari yang wajib melaporkan SPT (Linangkung, 2017). Kulonprogo dan Sleman merupakan dua kabupaten di D.I Yogyakarta. Berdasarkan data yang diperoleh dari KADIN DIY, Kabupaten Sleman merupakan wilayah di Yogyakarta dengan jumlah badan usaha yang terdaftar sebanyak 98 badan usaha, sedangkan Kulonprogo merupakan wilayah di Yogyakarta dengan jumlah badan usaha yang terdaftar sebanyak 5 badan usaha.

Rendahnya tingkat kepatuhan wajib pajak di Indonesia mendorong pemerintah membuat strategi yang mampu mendorong wajib pajak untuk patuh membayar pajak. Salah satunya adalah dengan pemanfaatan e-filing. Wajib Pajak dapat menggunakan e-filing agar tidak perlu lagi antri berjam-jam di Kantor Pelayanan Pajak hanya untuk menyampaikan SPT Tahunan-nya melalui internet. Pemerintah menerapkan E-filing atas dasar masih rendahnya tingkat kepatuhan wajib pajak dalam membayar pajak pada jumlah wajib pajak yang terdaftar (Dessy dkk, 2017). Penelitian Dessy dkk (2017) menunjukkan bahwa penerapan e-filing mempengaruhi kepatuhan wajib pajak.

Kepatuhan wajib pajak juga dapat ditingkatkan melalui peningkatan pemahaman wajib pajak. Pemahaman wajib pajak terhadap peraturan perpajakan adalah salah satu langkah wajib pajak untuk memahami peraturan perpajakan yang sudah ada. Penelitian yang dilakukan oleh Purba (2016) menunjukkan bahwa terdapat pengaruh yang signifikan antara pemahaman wajib pajak dengan kepatuhan wajib pajak. Kepatuhan wajib pajak juga dapat ditingkatkan dengan meningkatkan kualitas pelayanan. Kualitas pelayanan ini dapat ditingkatkan melalui peningkatan kemampuan dalam bidang perpajakan, memperluas tempat pelayanan terpadu, dan menggunakan sistem teknologi dan informasi untuk mempercepat pelayanan perpajakan. Usaha-usaha tersebut, diharapkan dapat meningkatkan kepuasan wajib pajak terhadap pelayanan pajak sehingga wajib pajak semakin patuh dalam membayar pajak (Supadmi, 2009).

Sanksi pajak adalah jaminan bahwa ketentuan peraturan perundang-undangan perpajakan (norma perpajakan) akan dipatuhi. Dengan adanya sanksi pajak ini, diharapkan wajib pajak menjadi patuh dalam membayar pajak secara tepat waktu. Penelitian Rahayu (2017) menunjukkan bahwa ketegasan sanksi pajak berpengaruh positif terhadap kepatuhan wajib pajak. Manfaat praktis dari penelitian diharapkan penelitian ini memberikan bahan pertimbangan dan sumbangan pikiran bagi Direktorat Jenderal Pajak didalam penyelenggaraan kebijakan dalam rangka upaya meningkatkan kepatuhan Wajib Pajak dalam melaksanakan kewajibannya. Manfaat Teoritisnya menambah pengetahuan serta sebagai bahan perbandingan antara teori yang diterima selama perkuliahan dengan praktek-praktek sebenarnya yang terjadi di lingkungan kerja. Tujuan penelitian Pertama 
untuk mendapatkan bukti empiris pengaruh kemanfaatan E-filing terhadap kepatuhan Wajib Pajak, kedua untuk mendapatkan bukti empiris pengaruh Pemahaman Wajib pajak terhadap kepatuhan Wajib Pajak, Ketiga untuk mendapatkan bukti empiris pengaruh Kualitas Pelayanan terhadap kepatuhan Wajib Pajak dan mendapatkan bukti empiris pengaruh Sanksi Perpajakan berpengaruh positif terhadap kepatuhan Wajib Pajak.

\section{METODE PENELITIAN}

Penelitian ini bersifat ex-post facto. Teknik pengumpulan data dalam penelitian ini menggunakan angket atau kuesioner. Pendekatan penelitian ini adalah kuantitatif dengan metode analisis statistic. Teknik analisis data memakai uji prasyarat,yaitu dengan: Uji Normalitas, Multikolinieritas, Heteroskedastisitas dihitung dengan menggunakan bantuan komputer program SPSS.15. Populasi dalam penelitian ini wajib pajak badan yang terdaftar di Kantor Pelayanan Pajak Pratama kabupaten Kulon Progo dan Sleman dengan jumlah sample penelitian sebanyak 85 Wajib Pajak. Untuk mengantisipasi tidak kembalinya atau tidak lengkapnya pengisian kuesioner, maka peneliti membulatkan menjadi 90 Wajib Pajak.

\section{HASIL DAN PEMBAHASAN}

1. Karakteristik Responden

Tabel 1

Karakteristik Responden Menurut Jenis Kelamin

\begin{tabular}{lcc}
\hline \multicolumn{1}{c}{ Jenis Kelamin } & Frekuensi & Persentase \\
\hline Laki-Laki & 56 & 62,2 \\
Perempuan & 34 & 37,8 \\
Jumlah & 90 & 100,0 \\
\hline
\end{tabular}

Berdasarkan tabel 1 dapat diketahui bahwa responden berjenis kelamin laki-laki yaitu sebanyak 56 orang $(62,2 \%)$ dan sebanyak 34 orang $(37,8 \%)$ berjenis kelamin perempuan. Dengan demikian dapat disimpulkan bahwa mayoritas responden dalam penelitian ini berjenis kelamin lakilaki.

Tabel 2

Karakteristik Responden Menurut Usia

\begin{tabular}{|c|c|c|}
\hline Usia & Frekuensi & Persentase \\
\hline $26-35$ tahun & 52 & 57,8 \\
\hline $36-45$ tahun & 10 & 11,1 \\
\hline $46-55$ tahun & 0 & 0,0 \\
\hline $56-65$ tahun & 28 & 31,1 \\
\hline$>65$ tahun & 0 & 0,0 \\
\hline Jumlah & 90 & 100,0 \\
\hline
\end{tabular}

Tabel 3

Karakteristik Responden Menurut Pendidikan

\begin{tabular}{lcc}
\hline \multicolumn{1}{c}{ Pendidikan } & Frekuensi & Persentase \\
\hline SMA & 0 & 0,0 \\
Diploma & 11 & 12,2 \\
Sarjana & 79 & 87,8 \\
Magister (S2) & 0 & 0,0 \\
Lainnya & 0 & 0,0 \\
Jumlah & 90 & 100,0 \\
\hline
\end{tabular}


Terlihat tabel 2 dapat bahwa responden yang berusia 26 - 35 tahun sebanyak 52 orang $(57,8 \%)$, berusia 36 - 45 tahun sebanyak 10 orang $(11,1 \%)$ dan yang berusia 56 - 65 tahun sebanyak 28 orang $(31,1 \%)$. Dengan demikian dapat disimpulkan bahwa mayoritas responden dalam penelitian ini berusia antara 26 - 35 tahun.

Diketahui responden dengan pendidikan terakhir Diploma sebanyak 11 orang (12,2\%), dan sisanya berpendidikan Sarjana (S1) sebanyak 79 orang (87,8\%). Dengan demikian dapat disimpulkan bahwa mayoritas responden dalam penelitian ini mempunyai pendidikan terakhir Sarjana.

\section{Tabel 4}

Karakteristik Responden Menurut Jabatan

\begin{tabular}{lccc}
\hline & Jabatan & Frekuensi & Persentase \\
\hline Karyawan & 52 & 57,8 \\
Lainnya & 38 & 42,2 \\
Jumlah & 90 & 100,0 \\
\hline
\end{tabular}

Data diatas menunjukkan bahwa responden dengan jabatan karyawan sebanyak 52 orang $(57,8 \%)$, dan sisanya sebagai pimpinan sebanyak 38 orang $(42,2 \%)$. Dengan demikian dapat disimpulkan bahwa mayoritas responden dalam penelitian ini adalah karyawan.

\section{Pengujian}

\section{Uji Validitas}

Tabel 5

Hasil Uji Validitas

\begin{tabular}{|c|c|c|c|c|}
\hline Variabel & Item & Nilai $r$ & Nilai Sig & Keterangan \\
\hline \multirow[t]{13}{*}{ Kepatuhan } & Item 1 & 0,488 & 0,006 & Valid \\
\hline & Item 2 & 0,653 & 0,000 & Valid \\
\hline & Item 3 & 0,569 & 0,001 & Valid \\
\hline & Item 4 & 0,544 & 0,002 & Valid \\
\hline & Item 5 & 0,580 & 0,001 & Valid \\
\hline & Item 6 & 0,601 & 0,000 & Valid \\
\hline & Item 7 & 0,491 & 0,006 & Valid \\
\hline & Item 8 & 0,735 & 0,000 & Valid \\
\hline & Item 9 & 0,501 & 0,005 & Valid \\
\hline & Item 10 & 0,575 & 0,001 & Valid \\
\hline & Item 11 & 0,698 & 0,000 & Valid \\
\hline & Item 12 & 0,568 & 0,001 & Valid \\
\hline & Item 13 & 0,773 & 0,000 & Valid \\
\hline \multirow[t]{4}{*}{ Kemanfaatan $E$-filing } & Item 1 & 0,810 & 0,000 & Valid \\
\hline & Item 2 & 0,797 & 0,000 & Valid \\
\hline & Item 3 & 0,721 & 0,000 & Valid \\
\hline & Item 4 & 0,787 & 0,000 & Valid \\
\hline \multirow[t]{3}{*}{ Pemahaman wajib pajak } & Item 1 & 0,936 & 0,000 & Valid \\
\hline & Item 2 & 0,796 & 0,000 & Valid \\
\hline & Item 3 & 0,956 & 0,000 & Valid \\
\hline \multirow[t]{5}{*}{ Kualitas pelayanan } & Item 1 & 0,700 & 0,000 & Valid \\
\hline & Item 2 & 0,714 & 0,000 & Valid \\
\hline & Item 3 & 0,830 & 0,000 & Valid \\
\hline & Item 4 & 0,654 & 0,000 & Valid \\
\hline & Item 5 & 0,538 & 0,002 & Valid \\
\hline \multirow[t]{2}{*}{ Sanksi pajak } & Item 1 & 0,873 & 0,000 & Valid \\
\hline & Item 2 & 0,684 & 0,000 & Valid \\
\hline
\end{tabular}

Sumber: Data primer diolah, 2019 
Berdasarkan hasil uji validitas yang dilakukan terhadap 30 orang dengan menggunakan korelasi product moment diperoleh hasil bahwa seluruh item pernyataan pada masing-masing variabel dalam penelitian ini valid. Hasil selengkapnya dapat dilihat pada tabel di bawah ini.

Tabel 5 menunjukkan bahwa seluruh item pernyataan mempunyai nilai $\rho$ hitung $<0,05$ sehingga dapat disimpulkan bahwa seluruh item pernyataan valid.

\section{Uji Reliabilitas}

Tabel 6

Hasil Uji Reliabilitas

\begin{tabular}{lcc}
\hline \multicolumn{1}{c}{ Instrumen } & Nilai Alpha & Keterangan \\
\hline Kepatuhan WP & 0,849 & Reliabel \\
Kemanfaatan $\boldsymbol{E}$-filing & 0,773 & Reliabel \\
Pemahaman WP & 0,878 & Reliabel \\
Kualitas pelayanan & 0,724 & Reliabel \\
Sanksi pajak & 0,744 & Reliabel \\
\hline
\end{tabular}

Sumber: Data primer diolah, 2019

Tabel 6 menunjukkan bahwa seluruh instrument penelitian mempunyai nilai alpha $>0,60$. Dengan demikian dapat disimpulkan bahwa seluruh instrument reliabel.

\section{Hasil Penelitian}

\section{Uji Asumsi Klasik}

a. Uji Normalitas

Uji normalitas digunakan untuk menguji apakah dalam model regresi, variabel penganggu atau residual memiliki distribusi normal atau tidak. Model regresi yang baik adalah distribusi data normal atau mendekati normal.

Tabel 7

Hasil Pengujian Normalitas Data

\begin{tabular}{ccc}
\hline One Kolmogorov-Smirnov & Nilai Sig. & keterangan \\
\hline Unstandardized Residual & 0,858 & Data Normal \\
\hline
\end{tabular}

Sumber : Data primer yang diolah, 2019

Tabel 7 di atas menunjukkan nilai signifikansi sebesar 0,858 >0,05 sehingga dapat diartikan bahwa dalam model regresi, variabel penganggu atau residual memiliki distribusi normal.

b. Uji Multikolinieritas

Pengujian ini bertujuan untuk mengetahui ada tidaknya korelasi dua atau lebih antar variabelvariabel independen yang masuk ke dalam model regresi.

Tabel 8

Hasil Pengujian Multikolinieritas

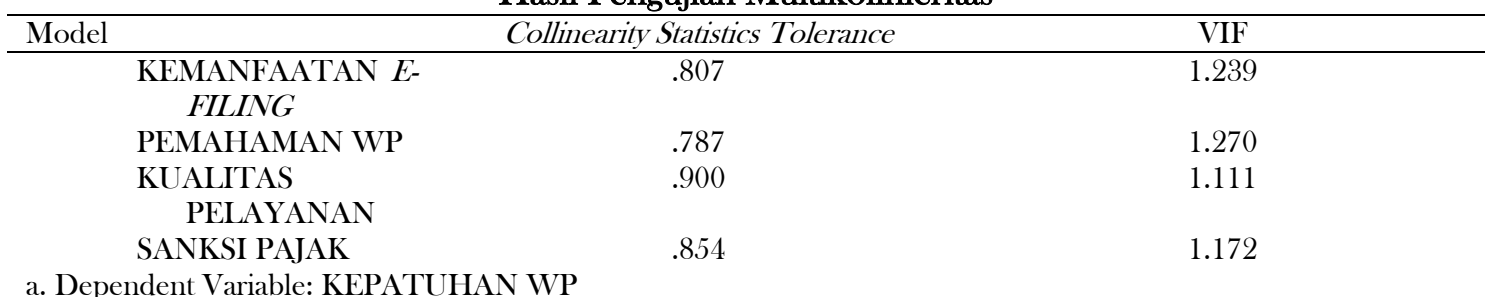

Sumber : Data primer yang diolah, 2019 
Tabel 8 menunjukkan bahwa variabel kemanfaatan e-filing mempunyai nilai VIF sebesar 1,239, pemahaman wajib pajak memiliki nilai VIF sebesar 1,270, variabel kualitas pelayanan sebesar 1,111 dan variabel sanksi pajak mempunyai nilai VIF sebesar 1,172. Keempat variabel independen tersebut mempunyi nilai VIF < 10, sehingga dapat disimpulkan bahwa dalam model regresi tidak terjadi korelasi antar variabel bebasnya.

c. Uji Heteroskedastisitas

Pengujian ini bertujuan untuk menguji apakah dalam model regresi terjadi ketidaksamaan varians dari residual satu pengamatan ke pengamatan yang lain. Berikut ini hasil pengujian heteroskedastisitas dengan uji Gleijser.

Tabel 9

Hasil Pengujian Heteroskedastisitas

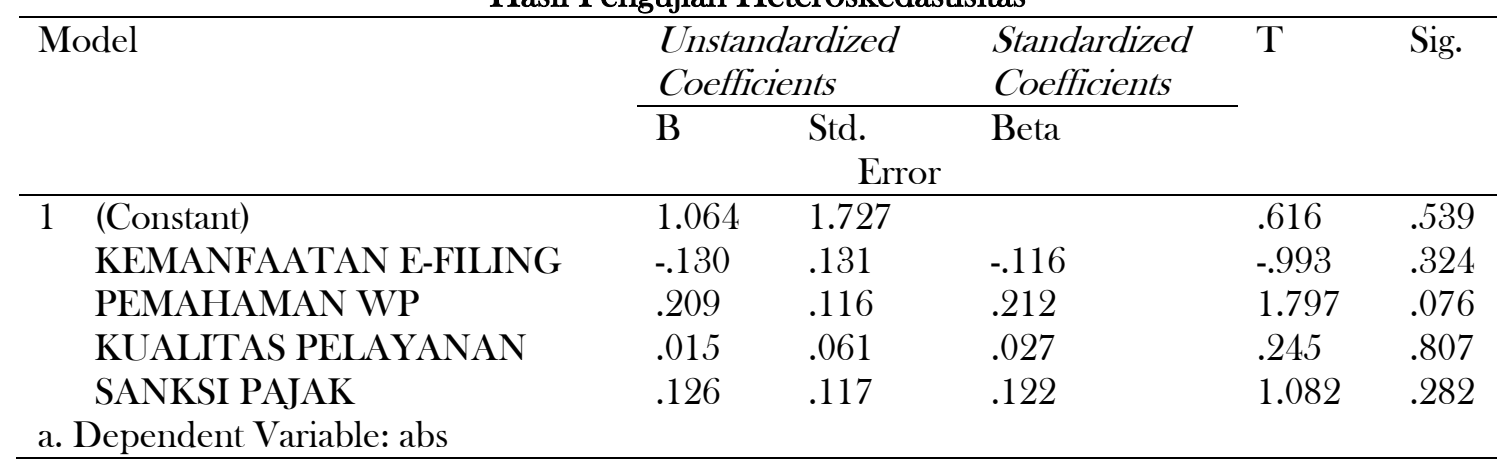

Sumber : Data primer yang diolah, 2019

Tabel 9 menunjukkan bahwa semua variabel independen (kemanfaatan e-filing, Pemahamanan WP, Kualitas Pelayaan dan Sanksi Pajak) mempunyai nilai signifikansi > 0,05 sehingga dapat disimpulkan dalam model regresi tidak terjadi heteroskedastisitas.

\section{Uji Hipotesis}

a. Interpretasi Analisis Regresi Linier Berganda

Tabel 10

Hasil Regresi Linier Berganda

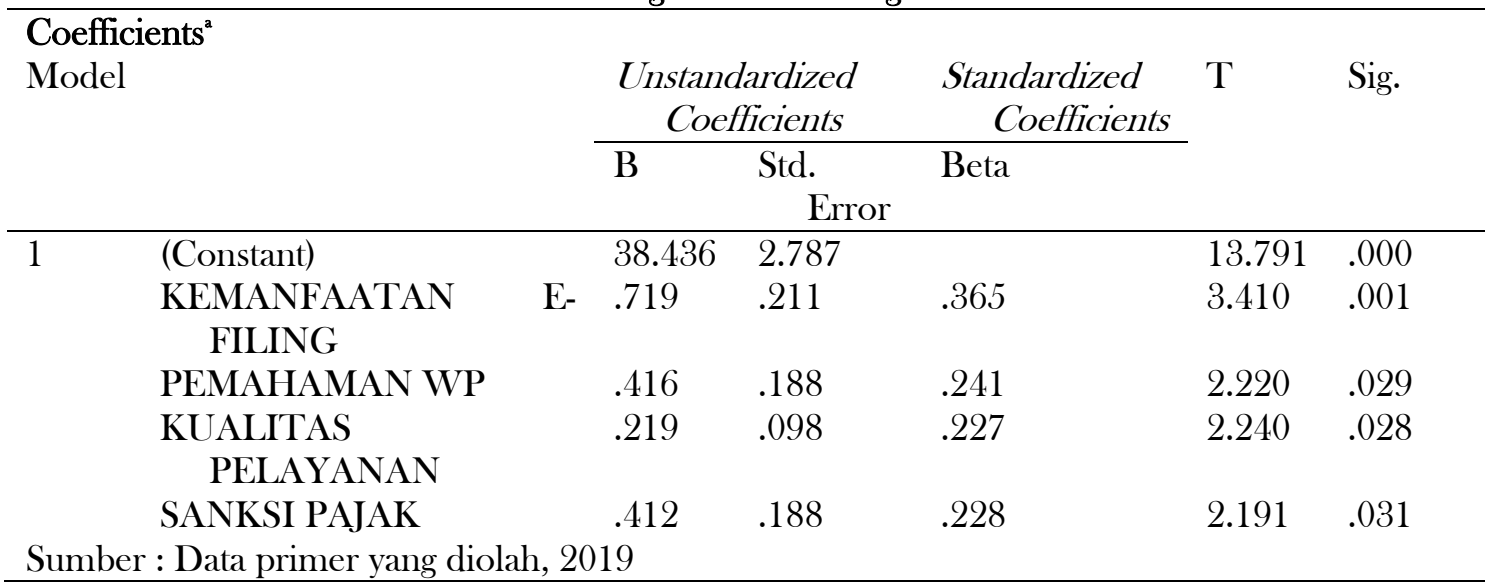

Berdasarkan tabel 10 dapat disusun persamaan regresi sebagai berikut.

$$
\mathrm{Y}=38,436+0,719 \mathrm{X}_{1}+0,416 \mathbf{X}_{2}+0,219 \mathrm{X}_{3}+0,412 \mathrm{X}_{4}
$$


Persamaan di atas dapat diinterpretasikan sebagai berikut

1) Konstanta (Koefisien a)

Nilai konstanta sebesar 38,436, menunjukkan bahwa jika variabel kemanfaatan e-filing, pemahaman WP, kualitas pelayanan dan sanksi pajak tidak ada, maka wajib pajak akan tetap patuh dengan nilai sebesar 38,436.

2) Koefisien regresi kemanfaatan e-filing $\left(\mathrm{b}_{1}\right)$

Variabel kemanfaatan e-filing $\left(\mathrm{X}_{1}\right)$ mempunyai koefisien regresi sebesar 0,719. Koefisien regresi yang positif, menunjukkan pengaruh yang searah antara kemanfaatan e-filing dengan kepatuhan wajib pajak. Artinya semakin tinggi kemanfaatan e-filing maka akan semakin tinggi kepatuhan wajib pajak dengan asumsi cateris paribus.

3) Koefisien regresi pemahaman wajib pajak $\left(\mathrm{b}_{2}\right)$

Variabel pemahaman wajib pajak $\left(\mathrm{X}_{2}\right)$ mempunyai koefisien regresi sebesar 0,416. Koefisien regresi yang positif, menunjukkan pengaruh yang searah antara pemahaman wajib pajak dengan kepatuhan wajib pajak. Artinya semakin tinggi pemahaman wajib pajak maka akan semakin tinggi juga tingkat kepatuhan wajib pajak dengan asumsi cateris paribus.

4) Koefisien regresi kualitas pelayanan

Variabel kualitas pelayanan pajak $\left(X_{3}\right)$ mempunyai koefisien regresi sebesar 0,219. Koefisien regresi yang positif, menunjukkan pengaruh yang searah antara kualitas pelayanan pajak dengan kepatuhan wajib pajak. Artinya semakin baik kualitas pelayanan pajak maka akan semakin tinggi tingkat kepatuhan wajib pajak dengan asumsi cateris paribus.

5) Koefisien regresi sanksi pajak

Variabel sanksi pajak $\left(X_{4}\right)$ mempunyai koefisien regresi sebesar 0,412. Koefisien regresi yang positif, menunjukkan pengaruh yang searah antara kualitas pelayanan pajak dengan kepatuhan wajib pajak. Artinya semakin tegas sanksi pajak yang diterapkan maka akan semakin tinggi tingkat kepatuhan wajib pajak dengan asumsi cateris paribus.

b. Uji Signifikansi Simultan

\section{Tabel 11}

Hasil Uji F

\begin{tabular}{lllllll}
\hline Model & & Sum of Squares & Df & Mean Square & F & Sig. \\
& Regression & 277.395 & 4 & 69.349 & 5.796 & .000 \\
& Residual & 1017.005 & 85 & 11.965 & & \\
& Total & 1294.400 & 89 & & & \\
\hline
\end{tabular}

Sumber : Data primer yang diolah, 2019

Berdasarkan hasil analisis pada tabel 1 , diperoleh nilai probabilitas signifikansi sebesar 0,000 $<0,05$. Hal ini berarti secara simultan variable kemanfaatan e-filing, pemahamanan WP, kualitas pelayaan dan sanksi pajak mempunyai pengaruh yang signifikan terhadap tingkat kepatuhan wajib pajak.

c. Uji Signifikansi Pengaruh Parsial 
Tabel 12

Hasil Uji T

\begin{tabular}{lll}
\hline \multicolumn{1}{c}{ Model } & Sig \\
\hline Kemanfaatan e-Filing & .001 & \\
Pemahaman Wp & .029 & \\
Kualitas pelayanan & .028 & \\
Sanksi pajak & .031 & \\
\hline
\end{tabular}

Berdasarkan hasil analisis data yang ditunjukkan Tabel 12 diperoleh nilai signifikansi (pvalue) variable kemanfaatan e-filing sebesar 0,001 , dikarenakan nilai p-value lebih kecil dari nilai $\alpha$ $=5 \%$ atau $(0,001<0,05)$, maka dapat dinyatakan variabel kemanfaatan e-filing berpengaruh signifikan terhadap tingkat kepatuhan wajib pajak. Hal ini berari $\mathrm{H} 1$ diterima.

Variabel pemahaman wajib pajak mempunyai nilai signifikansi (p-value) sebesar 0,029 , dikarenakan nilai p-value lebih kecil dari nilai $\alpha=5 \%$ atau $(0,029<0,05)$, maka dapat dinyatakan variabel pemahaman wajib pajak berpengaruh signifikan terhadap tingkat kepatuhan wajib pajak. Hal ini berari $\mathrm{H} 2$ diterima.

Variabel kualitas pelayanan pajak mempunyai nilai signifikansi (p-value) sebesar 0,028, dikarenakan nilai p-value lebih kecil dari nilai $\alpha=5 \%$ atau $(0,028<0,05)$, maka dapat dinyatakan variabel kualitas pelayanan pajak berpengaruh signifikan terhadap tingkat kepatuhan wajib pajak. Hal ini berari $\mathrm{H} 3$ diterima.

Variabel sanksi pajak mempunyai nilai signifikansi (p-value) sebesar 0,031, dikarenakan nilai p-value lebih kecil dari nilai $\alpha=5 \%$ atau $(0,031<0,05)$, maka dapat dinyatakan variabel sanksi pajak berpengaruh signifikan terhadap tingkat kepatuhan wajib pajak. Hal ini berari $\mathrm{H} 4$ diterima.

d. Uji Koefisien Determinasi

Tabel 13

Hasil Uji Koefisien Determinasi

\begin{tabular}{llllll}
\hline Model & R & R Square & Adjusted R Square & $\begin{array}{c}\text { Std. Error of the } \\
\text { Estimate }\end{array}$ & \\
\hline 1 & $.463^{\mathrm{a}}$ & .214 & .177 & 3.459 & \\
\hline
\end{tabular}

Sumber : Data primer yang diolah, 2019

Tabel 13 di atas menunjukkan nilai adjusted $R$ square sebesar 0,177. Artinya sumbangan variabel indeependen terhadap tingkat kepatuhan wajib pajak adalah sebesar 17,7\%. Sisanya sebesar 82,3\% dipengaruhi oleh faktor lain di luar penelitian ini.

\section{Pembahasan}

\section{Pengaruh Kemanfaatan E-Filing Pada Kepatuhan Wajib Pajak}

Berdasarkan hasil analisis menunjukkan bahwa variabel kemanfaatan e-filing berpengaruh signifikan terhadap kepatuhan wajib pajak ditunjukkan oleh nilai sig sebesar $0,001<0,05$. Artinya, semakin tinggi manfaat e-filing maka akan semakin tinggi kepatuhan wajib pajak. Sebaliknya, semakin rendah manfaat e-filing maka akan semakin rendah juga kepatuhan wajib pajak. e-filing merupakan Surat Pemberitahuan secara elektronik yang disampaikan Wajib Pajak melalui perusahaan ASP yang ditunjuk oleh Direktur Jenderal Pajak (Wulandari dkk, 2017). Untuk menggunakan e-filing, wajib pajak harus mempunyai e-FIN. e-FIN merupakan nomor yang digunakan wajib pajak untuk menyampaikan SPT Tahunan melalui internet. e-FIN diperoleh dengan mengajukan permohonan kepada Kantor Pelayanan Pajak terdekat atau langsung melalui website. Dengan e-FIN, wajib pajak dapat menggunakan e-filing agar tidak perlu lagi antri berjamjam di Kantor Pelayanan Pajak hanya untuk menyampaikan SPT Tahunan-nya. Dengan adanya efiling diharapkan tidak ada lagi alasan bagi wajib pajak untuk menunda menyerahkan SPT-nya 
hanya karena tidak mempunyai waktu. Hal ini menunjukkan bahwa e-filing memberikan manfaat yang tinggi bagi wajib pajak. Hasil penelitian ini sesuai dengan penelitian Dessy dkk (2017) menunjukkan bahwa penerapan e-filing mempengaruhi kepatuhan wajib pajak.

\section{Pengaruh Pemahaman Wajib Pajak Terhadap Kepatuhan Wajib Pajak.}

Hasil analisis kedua membuktikan bahwa variabel pemahaman wajib pajak berpengaruh signifikan terhadap terhadap kepatuhan wajib pajak, ditunjukkan oleh nilai sig sebesar 0,029<0,05. Artinya, semakin tinggi pemahaman wajib pajak mengenai perpajakan maka kepatuhan wajib pajak akan semakin tinggi. Sebaliknya, semakin rendah pemahaman wajib pajak mengenai perpajakan maka kepatuhan wajib pajak juga akan semakin rendah. Pemahaman wajib pajak terhadap peraturan perpajakan adalah salah satu langkah wajib pajak untuk memahami peraturan perpajakan yang sudah ada. Seperti yang diungkapkan oleh Dessy dkk (2017) bahwa pemahaman wajib pajak merupakan suatu keadaan dimana wajib pajak mengerti dan paham mengenai ketentuan umum dan tata cara perpajakan tentang bagaimana cara membayar pajak, melaporkan SPT, mengetahui dimana tempat membayar pajak, mengetahui kapan batas waktu pembayaran atau pelaporan SPT dan mengetahui sanksi yang diterimanya apabila tidak membayar pajak tepat waktu. Wajib pajak akan menjalankan seluruh peraturan perpajakan apabila dia memahami isi dari peraturan perpajakan tersebut. Wajib pajak yang kurang memahami peraturan perpajakan cenderung akan menjadi wajib pajak yang kurang taat, sedangkan wajib pajak yang memahami peraturan perpajakan dengan baik, tentu akan mematuhi peraturan perjakan (Hafiz dan Saryadi, 2017). Hasil penelitian ini sesuai dengan penelitian yang dilakukan oleh Purba (2016) yang menunjukkan bahwa terdapat pengaruh yang signifikan antara pemahaman wajib pajak dengan kepatuhan wajib pajak.

\section{Pengaruh Kualitas Pelayanan Terhadap Kepatuhan Wajib Pajak.}

Hasil analisis ketiga membuktikan bahwa variabel kualitas pelayanan pajak berpengaruh signifikan terhadap terhadap kepatuhan wajib pajak, ditunjukkan oleh nilai sig sebesar 0,028<0,05. Artinya, semakin baik kualitas pelayanan pajak maka kepatuhan wajib pajak akan semakin tinggi. Sebaliknya, semakin buruk kualitas pelayanan pajak maka kepatuhan wajib pajak juga akan semakin rendah. Kualitas pelayanan pajak merupakan suatu keadaan dinamis yang berkaitan dengan produk, jasa manusia, proses dan lingkungan terkait pepajakan yang sesuai atau di atas harapan wajib pajak. Kualitas pelayanan pajak berkaitan dengan kepatuhan wajib pajak. Jika pelayanan yang dilaksanakan pegawai pajak baik dan memberikan kesan positif kepada wajib pajak maka terdapat kemungkinan wajib pajak akan menyampaikan SPT Tahunannya dengan rajin dan tepat dalam membayar pajak. Dengan kata lain, apabila wajib pajak merasa bahwa kualitas pelayanan pajak melebihi harapannya maka wajib pajak akan patuh terhadap norma perpajakan. Sebaliknya, bila wajib pajak merasa bahwa kualitas pelayanan perpajakan tidak sesuai harapannya, maka wajib pajak cenderung untuk malas membayar pajak. Menurut Surat Edaran Direktur Jenderal Pajak Nomor SE-84/PJ/2011 tentang Pelayanan Prima menyebutkan bahwa pelayanan yang baik adalah sentra dan indikator utama dalam membangun citra Direktorat Jenderal Pajak, sehingga kualitas pelayanan harus terus menerus ditingkatkan dalam rangka mewujudkan harapan dan membangun kepercayaan seluruh stakeholder perpajakan terhadap Direktorat Jenderal Pajak. Hasil penelitian ini sesuai dengan penelitian Abdi (2017) menunjukkan bahwa kualitas pelayanan fiskus berpengaruh positif terhadap kepatuhan wajib pajak.

\section{Pengaruh Sanksi Perpajakan Terhadap Kepatuhan Wajib Pajak.}

Hasil analisis keempat membuktikan bahwa variabel sanksi pajak berpengaruh signifikan terhadap terhadap kepatuhan wajib pajak, ditunjukkan oleh nilai sig sebesar $0,031<0,05$. Artinya, semakin baik sanksi pajak maka kepatuhan wajib pajak akan semakin tinggi. Sebaliknya, semakin buruk sanksi pajak maka kepatuhan wajib pajak juga akan semakin rendah. Sanksi pajak merupakan suatu alat yang digunakan untuk mencegah terjadinya pelanggaran norma perpajakan oleh wajib 
pajak. Sanksi pajak dapat berupa sanksi administrasi dan sanksi pidana yang berlaku bagi wajib pajak, fiskus dan pihak ketiga. Sanksi administrasi meliputi sanksi denda, snksi bunga dan sanksi kenaikan. Sanksi pidana meliputi denda pidana, denda kurungan dan dendara penjara (Resmi, 2003). Sanksi perpajakan sebagai jaminan bahwa wajib pajak mematuhi ketentuan Undang-Undang Perpajakan. Penerapan sanksi pajak yang tegas diharapkan dapat meminimalisir pelanggaran yang terjadi. Semakin tegas sanksi pajak yang diberlakukan, maka semakin tinggi kepatuhan wajib pajak dalam membayar pajaknya. Hasil penelitian ini sesuai dengan penelitian Arabella (2013) menunjukkan bahwa sanksi perpajakan yang dilakukan dengan tegas mempunyai pengaruh yang positif terhadap kepatuhan pelaporan wajib pajak.

\section{KESIMPULAN}

Dilakukannya penelitian ini mempunyai tujuan unuk mengetahui kemanfaatan E-Filing, Pemahaman Wajib Pajak, Kualitas Pelayanan, dan Sanksi Perpajakan terhadap Kepatuhan Wajib Pajak di Kabupaten Kulon Progo dan Sleman. Berdasarkan hasil analisis pada bab sebelumnya, maka dapat disimpulkan bahwa: (1) Kemanfaatan e-filing berpengaruh signifikan terhadap kepatuhan wajib pajak. (2) Pemahaman wajib pajak berpengaruh signifikan terhadap kepatuhan wajib pajak. (3) Kualitas pelayanan pajak berpengaruh signifikan terhadap kepatuhan wajib pajak. (4) Sanksi pajak berpengaruh signifikan terhadap kepatuhan wajib pajak.

Berikut adalah saran yang diberikan peneliti untuk peneliti selanjutnya: (1) Bagi instansi terkait diharapkan dapat meningkatkan pelayanan melalui e-filing, pemahaman wajib pajak dan memberlakukan sanksi pajak dengan tegas, sehingga wajib pajak semakin patuh dalam memenuhi kewajibannya. (2) Bagi penelitian selanjutnya, diharapkan dapat menambah variabel independen lain seperti pendapatan, pengetahuan dan lain sebagainya.

\section{DAFTAR PUSTAKA}

Abadi, R. (2016). Manfaat Pajak bagi masyarakat dan Negara. http://cermati.com. Diakses tanggal 10 Maret 2019

Abdi, R. (2017). Pengaruh Sanksi Pajak, Kualitas Pelayanan dan Penerapan Sistem e-Filling terhadap Kepatuhan Wajib Pajak Orang Pribadi. Skripsi. Universitas Negeri Padang.

Arabella O.F \& Yenni M. (2013). Pengaruh Kualitas Pelayanan Petugas Pajak, Sanksi Perpajakan dan Biaya Kepatuhan Pajak terhadap Kepatuhan Wajib Pajak UMKM. Tax \& Accounting Review. 1(1)

Arikunto. (2006). Prosedur Penelitian Suatu Pendekatan Praktik. Jakarta: Rineka Cipta

Dessy, A. W. \& Nourwahida, C.D. (2017). Analisis Faktor-Faktor yang Mempengaruhi Kepatuhan Wajib Pajak Orang Pribadi (Studi Kasus di KPP Pratama Kalideres Jakarta Barat). Diskusi Panel Nasional Pendidikan Kewirausahaan. LPPM Universitas Indraprasta PGRI Jakarta.

Fajriyan, N. A. (2015). Pengaruh Persepsi Pelaksanaan Sensus Pajak Nasional, Sikap Wajib Pajak pada Pelaksanaan Sanksi Denda dan Kesadaran Perpajakan terhadap Kepatuhan Wajib Pajak (Studi pada Wajib Pajak Orang Pribadi di Kelurahan Miji Kota Mojokerto). Naskah Publikasi. Fakultas Ekonomi Universitas Brawijaya.

Ghozali, I. (2011). Aplikasi Analisis Multivariate dengan Program IBM SPSS For Windows. Semarang: BP Undip

Hafiz \& Saryadi. (2017). Pengaruh Sosialisasi Wajib Pajak terhadap kepatuhan Wajib pajak melalui Pemahaman Wajib Pajak sebagau Variabel Intervening. Naskah Publikasi. Universitas Diponegoro

Jayanto, P. Y. (2011). Faktor-Faktor Ketidakpatuhan Wajib Pajak. Jurnal Dinamika Manajemen. 2(1) 
Kusuma. (2018). Tingkat Kepatuhan Pajak Masyarakat RI Masih Rendah. https://finance.detik.com/berita-ekonomi-bisnis/d-4214299/tingkat-kepatuhan-pajakmasyarakat-ri-masih-rendah

Linangkung, E. (2017). Kepatuhan Wajib Pajak DIY Capai 92\%. https://ekbis.sindonews.com/read/1200843/33/kepatuhan-wajib-pajak-diy-capai-921493345445. Diakses tanggal 19 Agustus 2019

Mardiasmo. (2009). Perpajakan. Yogayakarta: Andi Offset

Masruroh, S. (2013). Pengaruh Manfaat NPWP, Pemahaman Wajib Pajak, Kualitas Pelayanan dan Sanksi terhadap Kepatuhan Wajib Pajak (Studi Empiris pada WP OP di Kabupaten Tegal). Skripsi. Fakultas Ekonomika dan Bisnis Universitas Diponegoro

Ompusunggu, A. (2011). Cara Legal Siasati Pajak. Jakarta: Puspa Swara

Priantara, D. (2012). Perpajakan Indonesia. Edisi 2. Jakarta: Mitra Wacana Mada.

Purba, M. (2016). Akuntansi Pajak Penghasilan. Yogyakarta: Graha Ilmu

Rahayu, N. (2017). Pengaruh Pengetahuan Perpajakan, Ketegasan Sanksi Pajak dan Tax Amnesty terhadap Kepatuhan Wajib Pajak. Akuntansi Dewantara. 1(1).

Rahayu, S. \& Ita, S. (2009). Pengaruh Modernisasi Sistem Administrasi Perpajakan terhadap kepatuhan Wajib Pajak. Jurnal Akuntansi. 1(2).

Rahman, A. (2010). Panduan pelaksanaan Administrasi Pajak: untuk Karyawan pelaku Bisnis Perusahaan. Bandung: Nuansa

Resmi, S. (2003). Perpajakan: Teori dan Kasus. Jakarta: Salemba Empat

Suandy, E. (2008). Hukum Pajak. Jakarta: Salemba Empat

Sugiyono. (2014). Metode Penelitian Kuantitatif Kualitatif dan R\&D. Bandung: Alfabeta

Sumarsan,T. (2012). Perpajakan Indonesia Edisi 2: Pedoman Perpajakan yang Lengkap Berdasarkan Undang-Undang Terbaru. Jakarta: Indeks

Supadmi, N. L. (2009). Meningkatkan Kepatuhan Wajib Pajak melalui Kualitas Pelayanan. Jurnal Akuntansi \& Bisnis. 4(2)

Tiraada, T. A. M. (2013). Kesadaran Perpajakan, Sanksi Pajak, Sikap Fiskus terhadap Kepatuhan WPOP di Kabupaten Minahasa Selatan. Jurnal/ISSN 2303-1174

Widyaningsih, A. (2013). Hukum Pajak dan perpajakan. Bandung: Alfabeta

Wulandari, R., Oktyawati, D., Natasari, D., Zamzami, F., \& Wardani, L. (2017). Modul: Pelatihan Pajak Aplikatif Brevet A\&B. Yogyakarta: BP UGM 